\title{
Impacts of flooding on coastal fishing folks and risk adaptation behaviours in Epe, Lagos State
}

\author{
A. S. Oyekale ${ }^{1 \star}$, O. I. Oladele ${ }^{1}$ and F. Mukela ${ }^{2}$ \\ ${ }^{1}$ Department of Agricultural Economics and Extension, North-West University Mafikeng Campus, \\ Mmabatho, 2735 South Africa. \\ ${ }^{2}$ Department of Agricultural Economics, University of Ibadan, Ibadan, Oyo State, Nigeria.
}

Accepted 9 July, 2013

\begin{abstract}
Climatic changes have made flooding a major environmental hazard in the coastal areas of Nigeria. This study assessed the impacts and households' adaptation mechanisms in Epe Division of Lagos State. Data obtained from some fishing folks were subjected to descriptive, Probit regression and Tobit regressions analytical methods. The results show that the adverse impacts of flooding reduce with ability to migrate, monthly income and possession of other secondary occupations. The females, educated and rich among the fishing folks are willing to pay significantly higher amounts on insurance against flooding. The study recommended that efforts to address flooding should include alternative skill development, migration, offering of assistances, provision of affordable and quality health services for the treatment of malaria, cholera and dysentery and proper development of early warning signal, among other.
\end{abstract}

Key words: Flooding, climate change, impact, vulnerability, fishing folks.

\section{INTRODUCTION}

In 1976, international communities ratified the right to adequate housing and continuous improvement of living conditions as contained in the International Covenant on Economic, Social and Cultural Rights (The Office of the High Commission for Human Right). This pledge was reactivated at the UN Millennium Summit where, in line with the Millennium Development Goals (MDGs), some specific targets for realizing a significant improvement in the lives of at least 100 million slum dwellers' by 2020 was set. In recent years, however, climate change presents significant threats to the achievement of those laudable Millennium Development Goals (MDGs), especially those related to eliminating poverty and hunger and promoting environmental sustainability (United Nations, 2007). This is because, variations in rainfall and extreme weather events are likely to place additional strains on poorer countries already facing serious challenges due to food insecurity, indebtedness, HIV/AIDS, environmental degradation, armed conflicts, economic shocks and the negative effects of globalization (UNDP, no date). Therefore, attentions have been given to extreme weather events and climatic patterns resulting from global warming, which is caused by emission of green house gases (GHGs) like carbon dioxide $\left(\mathrm{CO}_{2}\right)$, methane $\left(\mathrm{CH}_{4}\right)$ and nitrous oxide $\left(\mathrm{N}_{2} \mathrm{O}\right)$. UN (2007) submitted that the primary contributor to climate change is carbon dioxide $\left(\mathrm{CO}_{2}\right)$, released by the burning of fossil fuels, whose concentration had reached 29 billion metric tons in 2004 and continue to rise, as evidenced by increasing concentrations of $\mathrm{CO}_{2}$ in the atmosphere.

The Intergovernmental Panel on Climate Change (IPCC) has linked the rise in sea level to climate change. Between 1960 and 1970, a mean sea level rise of 0.462 $\mathrm{m}$ was recorded along the Nigerian coastal water (Udofa 
and Fajemirokun, 1978). Flooding of low-lying areas in the Lagos and the coastal State of the Niger Delta region has been observed. Settlements in the coastal region have been uprooted by coastal erosion. The inundation arising from the rise in sea level will increase problems of floods, intrusion of sea-water into fresh water sources and ecosystems, destroying such stabilizing systems as mangroves, and affecting agriculture, fisheries and general livelihoods (Okali and Eleri, 2004). Occupants of some of the affected houses, who are unable to relocate for financial reasons, will have to cope with the situation. This makes them vulnerable to different kinds of waterrelated disease such as malaria, dysentery, cholera, and diarrhea. Trauma resulting from the problem can lead to nonpathogenic diseases such as hypertension and diabetes (Uyigue, 2007).

Murty (1984) defined storm surges as "oscillation of the water level in a coastal or inland water body in period range of few a minutes to a few days, resulting from forcing from weather system". Over the years, the combination of strong onshore winds, low atmospheric pressure and astronomical tides has often resulted in ocean surges and associated coastal flooding in Lagos State. The threat imposed by these surges and associated flood over the low-lying coast of Nigeria is becoming unbearable (Olaniyan and Afiesimama, 2002). The most serious flooding often results when an extreme storm surge event occurs concomitantly with a tidal maximum (Lowe et al., 2001). Water level during some ocean surges in Nigeria can rise up to about $5 \mathrm{~m}$ (Awosika et al., 1992). Surface waves and other coastal circulation changes can modify or amplify the impact of a surge in the coastal region.

Flood hazard is one of the most frequent and disastrous phenomena in the world (Marfai and King, 2007). Sivakumar (2005) noted that between 1993 and 2002 , there were 2,654 hazard events where floods and windstorms accounted for about $70 \%$ of the hazards while the remaining $30 \%$ of the disasters were brought about by droughts, landslides, forest fires, heat waves and others. The problem has also led to contamination of coastal water resources, decimation of coastal agricultural and recreational area, destruction of settlement and major roads, dislodgement of oil producing and export handling facilities, loss of properties, income and sometimes lives. The anomalous forcing is generally sustained for several days with largest disturbances arising from storm tracks (Komen and Smith, 1999).

Nigeria's high vulnerability to climate change mainly stems from its geographical location - in the tropics and with a long coastline. With climate change predicted to cause global sea level rise to which $29,000 \mathrm{~km}^{2}$ of Nigerian coastline is highly vulnerable, the frequency of incidence of extreme weather condition in the form of flooding resulting from ocean surge cannot be prevented (IPCC, 2001). Flooding in one form or other affects at least $20 \%$ of the nation's population. Flooding and its twin problem of erosion cause losses that run into billions of Naira per year (Ayo-Lawal, 2007). It should be noted that the types of flooding known to happen in Nigeria include flash floods (river flooding) after torrential rains, dam bursts which follow flash floods and urban flooding of low-lying areas with poor surface drainage as well as coastal flooding. The rainy season is marked by widespread phenomenon of flooding experienced due to heavy torrential rains or storm surge exacerbated by the low lying (coastal) topography, vulnerable soil characteristics, and intense wave and tidal action (UNESCO/CSI, 2000). Also, urbanization and population pressure with its attendant problems of poor land use leading to alterations and blockage of channels constitute the human induced causes of flooding like dumping of refuse in or erecting buildings on drainage routes.

It is pathetic to note that rural dwellers that are most vulnerable to climate change have the least capacity to adapt. Flooding becomes more severe when fishing communities that are located along the coasts are involved. This is due to high level of and their low adaptation mechanism. This study therefore assessed the impact of flooding among coastal fishing households in Epe Division of Lagos State and evaluated their adaptation mechanisms. It is expected that the findings from the study will pave ways for providing assistance to these vulnerable households.

\section{Conceptual framework}

This study adopted the livelihood strategies framework presented in Figure 1. It is the basis of most frameworks used in impact and adaptation studies such as the one utilized by Leary and Beresford (2007). This framework shows how the interactions between human induced factors and natural factors result in environmental hazards such as flooding. The exposure of vulnerable people, places and systems determines the amount of impact the hazards will have or the level of risk experienced.

Therefore, vulnerability to climatic hazards is a function of the interactions between sensitivities, capacities and resilience, which are all determined by humanenvironmental conditions and processes. Resilience is the amount of change a system can undergo without changing state (IPCC, 2001). These conditions and processes consist of demographic, social, economic, political, biophysical and ecological. Adaptation options of stakeholders are shown to be a function of information. The stakeholders include decision makers (or policy makers), vulnerable groups like fishermen, and the general public. From the figure, information on assessment of changes, vulnerabilities, exposures, risks/impacts, adaptation responses and driving forces must flow to and from the stakeholders.

Climate change is expected to manifest itself through change in frequency and magnitude of extreme events 


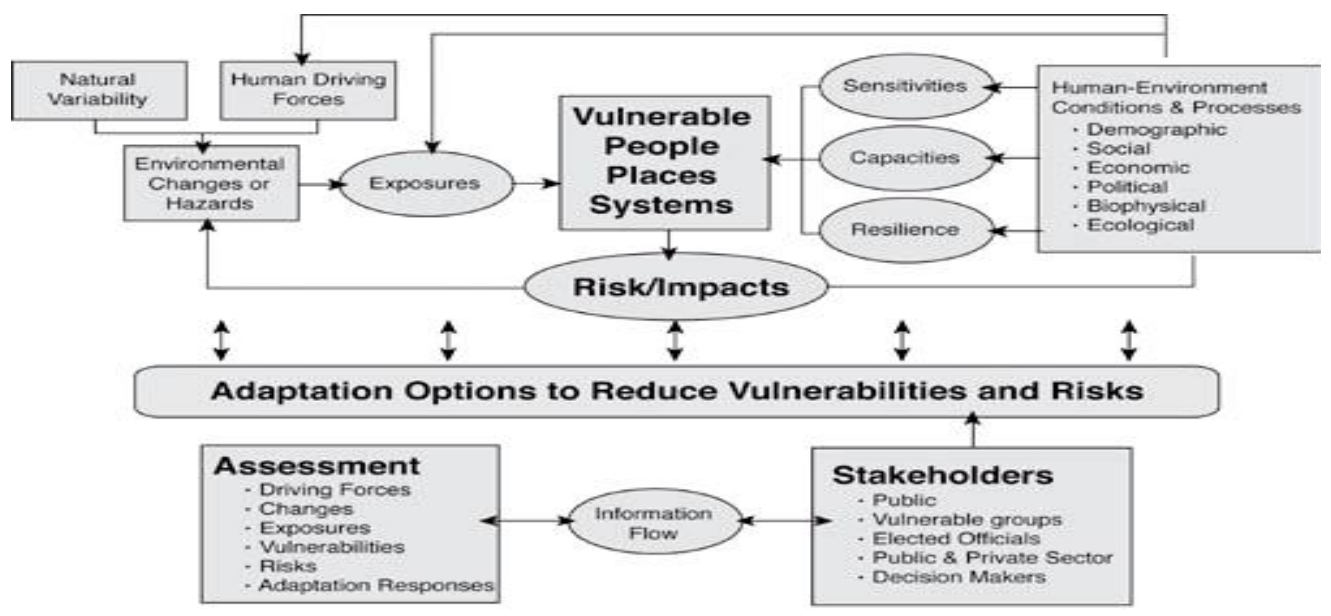

Figure 1. Vulnerability, adaptation and responses assessments (Leary and Beresford, 2007).

like flooding, drought, storm etc. (IPCC, 2001). Although there is dearth of data on the frequency of disasters due to climate change in many countries, Jepma and Munasinge (1998) estimate that with a $70 \mathrm{~cm}$ sea level rise, the number of people at risk of annual flooding could increase from 46 to 90 million. These changes (floods and storms) are expected to bring about, in addition to loss of biodiversity, life and livelihood, the spread of diseases such as cholera, dysentery, malaria and yellow fever and increase the chances of famine in areas with inadequate coping systems (Blaikie, 1994).

Literature maintains that areas where malaria is currentlyendemiccouldexperienceintensified transmission because flooding provides breeding ground while higher temperatures worsen the situation. Increases in nonvector-borne infectious diseases, such as salmonellosis, cholera and giardiasis, also could occur as a result of elevated temperatures and increased flooding. This means that a great obstacle stands in the way of achievement of the Millennium Development Goals because malaria is endemic in this part of Africa and translates into drastically reduced food production leading to food insecurity and all its attendant problems.

There are varieties of underutilized options for reducing flood, erosion and drought (Osman-Elasha et al., 2007). However, application of these measures depends to a large extent on perception of risk. Maddison (2006) reported that perception results on climate change showed that a significant number of farmers believe that temperature has already increased and that precipitation has declined. The study also reported that experience, access to free extension services and markets are important determinants of adaptation.

Since perception is the fundamental prerequisite of long-term livelihood adaptation facilitated by coordination of agency planning, communication and field operations activities, as well as the activities of government line agencies and departments, NGOs, and the rural people themselves; it follows that adaptation is to have a multisectoral approach. It should be participatory in nature to ensure sustainability and faster spread as well as effective use. It is also important to recognize that no single adaptation strategy can be encouraged, given the uniqueness of each situation. This is clearly recognized by UNFCCC (2002) which emphasizes the lack of a "one size fits all formula". Therefore, there is a need to identify existing knowledge and coping strategies of the poor as well as their risk perception which would determine their willingness to pay or adapt as well as the effectiveness of adaptation.

\section{MATERIALS AND METHODS}

\section{Area of study}

Lagos State, the city of aquatic splendour, was created on $27^{\text {th }}$ May, 1967 and lies to the South Western part of Nigeria. It has boundaries with Ogun State in the North and East, Republic of Benin in the West and the Atlantic Ocean in the South with a shore line stretch of $180 \mathrm{~km}$. It comprises five geographical divisions which are Epe, Ikorodu, Ikeja, Lagos and Badagry. Lagos has a population of 17 million out of the national estimate of 140 million in 2006 and an area of 356,861 ha of which 75,755 ha are wetlands. It has a maze of lagoons and waterways make up about $22 \%$ of the total landmass.

This study was carried out in Epe, which is a coastal town demarcated by a long range of hills into equal parts. Epe local government area has a total population of 323,634 people of which 153,360 are males (2006 census). Most of the inhabitants of the division engage in fishing and farming activities for their livelihood though the fishing activities is seasonal and synchronized to the lifecycle of the fish. The land is highly endowed with forest wood and the types of crops grown are rice, coconut, pineapple, cassava, cocoa, palm tree, banana or plantain, maize, vegetables and ginger favoring conditions. Silica sands, fish, reptiles, shrimps and bitumen are also extractable in the area.

\section{Sources and method of data collection}

This study used primary data that were collected through personal 
interviews that were aided by structured questionnaires. Simple random sampling technique was applied in this study. The respondents, which are fishermen were randomly selected. The selection of communities in Epe was based on degree of fishing activities and proximity to water source. Out of the 120 questionnaires distributed only 100 were returned of which only 94 were completely and properly filled by the respondents. The communities visited included Owode and Olowo market. These were chosen because of high degree of fishing activities.

\section{Method of data analysis}

The data collected from the field were processed using various statistical and analytical tools. These include simple statistical tools like frequencies, percentages, and descriptive statistics and cross tabulations.

\section{Probit regression}

In order to identify the factors explaining experiences of some forms of problems resulting from flooding, we used the Probit regression. We intended to estimate the factors explaining some probability values ranging between 0 and 1 . The dependent variable (Yi) will be binary with values of 1 if respondents answered yes to some questions of whether flooding is the major environmental problem, experienced activity disruption by flooding, experienced of property losses through flooding, experienced of death through flooding, experienced water contamination due to flooding and spend more on health immediately after flooding, and 0 otherwise. The model is stated as:

$$
Y_{i j}=\alpha_{j}+\beta_{j} \sum_{j=1}^{n} X_{i j}+e_{i}
$$

$X_{1}=\operatorname{sex}(1=$ male, 0 otherwise $), X_{2}=$ age of respondents in years, X3 $=$ marital status (married $=1,0$ otherwise), $X 4=$ household size, $X 5=$ years of education, $X 6=$ monthly income in Naira, $X 7=$ fishing experience in years, $X 8=$ association membership (yes $=1,0$ otherwise), $\mathrm{X} 8=$ malaria incidence increased during flooding, $\mathrm{X} 9=$ typhoid incidence increased during flooding (yes $=1,0$ otherwise), $\mathrm{X} 10=$ cholera incidence increased during flooding (yes $=1,0$ otherwise), X11 = diarrhea incidence increased during flooding (yes $=1,0$ otherwise), $X 12=$ dysentery incidence increased during flooding (yes $=1,0$ otherwise), X13 = influenza incidence increased during flooding i(yes $=1,0$ otherwise), X14 = tuberculosis incidence increased during flooding (yes $=1,0$ otherwise), $\mathrm{X} 15=$ more labour required during flooding (yes $=1,0$ otherwise), $X 16=$ fish species change during flooding (yes $=1,0$ otherwise), $\mathrm{X} 17$ = early warning received before flooding (yes $=1,0$ otherwise), $X 18=$ other occupation (yes $=1,0$ otherwise), $\mathrm{X} 19=$ received help during flooding (yes $=1,0$ otherwise); ei = error disturbance term.

\section{Tobit regression for risk insurance}

The fishing folks were asked for their willingness to participate in a functioning insurance program against flooding. We found this to be relevant given increasing attentions that are being given to issues of insurance companies and implementation of the National Heath Insurance Scheme (NHIS). The households were asked for the among they would be willing to pay monthly in order to secure a kind of insurance for their properties, in case of flooding. Because we have zero amounts, a Tobit model was estimated. The equation is given as:
$Z_{i}=\phi+\lambda_{j} \sum_{1=j}^{n} X_{j}+v$

Where $Z_{\mathrm{i}}$ is the amount willing to be paid and $\mathrm{Xs}$ are as defined for Equation (1).

\section{RESULTS AND DISCUSSION}

\section{Experience of flooding across socio-economic groups}

Table 1a shows that $88.30 \%$ of the fishing folks experienced one form of flooding or the other. Among these, $77.66 \%$ are males. The table also reveals that males have higher involvement in fishing as an occupation. This confirms earlier findings by various researchers such as Haakonsen (1992) and Jinadu (2003) that fishing is primarily done by males, although women are predominantly involved in the processing. Average age of the fishing folks is 36.42 years with $27.32 \%$ as the coefficient of variation. In Table $1 \mathrm{a}$, those that experienced flooding among those that are less than 30 years are $35.11 \%$ while $7.45 \%$ did not.

Average fishing experience is $9.64 \%$ with its variability index being $116.51 \%$. Based on the groupings of the fishing folks' experiences, among those that are less than 5 years in fishing, $39.36 \%$ experienced flooding, while only $8.51 \%$ have not experienced it. It should be noted that all those who indicated to have spent more than 16 years in fishing experienced flooding.

The table shows that $55.32 \%$ of the respondents are married and experienced flooding, while only $4.26 \%$ did not experience it. Average household size is 6.14 with standard deviation of 2.91. In the groupings contained in Table 1a, most of the respondents have household sizes of 5 to 6 , while the least have household size of more than 10 members. From this, it can be inferred that respondents have a larger human capital asset base which can be translated to enhanced capacity to cope especially if household members are in their productive phase of life. On the other hand, it may mean a reduced capacity to cope with stresses and shocks if household members are all dependent upon the household head. The table also reveals that most of the fisher folk lack formal education and only a small fraction managed to attend tertiary institutions. Also, $73.40 \%$ of the respondents primarily engage in fishing as means of livelihood. The results show that artisans, traders and farmers are among the most prominent occupations, besides fishing.

\section{Impact of flooding on fishing households}

We estimated some equations in order to assess the impacts of flooding on the fishing folks. These equations 
Table 1. Respondents' experience of flooding across some socio-economic groups.

\begin{tabular}{|c|c|c|c|c|c|c|}
\hline Socio-economic groups & Yes & Percent & No & Percent & Total frequency & Percent \\
\hline \multicolumn{7}{|l|}{ Sex } \\
\hline Male & 146 & 77.66 & 16 & 8.51 & 162 & 86.17 \\
\hline Female & 20 & 10.64 & 6 & 3.19 & 26 & 13.83 \\
\hline \multicolumn{7}{|l|}{ Age } \\
\hline less 30 & 66 & 35.11 & 14 & 7.45 & 80 & 42.55 \\
\hline $30-39$ & 46 & 24.47 & 4 & 2.13 & 50 & 26.60 \\
\hline $40-49$ & 26 & 13.83 & 2 & 1.06 & 28 & 14.89 \\
\hline $50-59$ & 24 & 12.77 & 2 & 1.06 & 26 & 13.83 \\
\hline More than 60 & 4 & 2.13 & 0 & 0.00 & 4 & 2.13 \\
\hline \multicolumn{7}{|l|}{ Fishing experience } \\
\hline $0-5$ & 74 & 39.36 & 16 & 8.51 & 90 & 47.87 \\
\hline $6-10$ & 29 & 15.43 & 4 & 2.13 & 33 & 17.55 \\
\hline $11-15$ & 18 & 9.57 & 2 & 1.06 & 20 & 10.64 \\
\hline $16-20$ & 26 & 13.83 & 0 & 0.00 & 26 & 13.83 \\
\hline More than 20 & 19 & 10.11 & 0 & 0.00 & 19 & 10.11 \\
\hline \multicolumn{7}{|l|}{ Household size } \\
\hline $2-4$ & 66 & 35.11 & 14 & 7.45 & 80 & 42.55 \\
\hline $5-6$ & 46 & 24.47 & 4 & 2.13 & 50 & 26.60 \\
\hline $7-8$ & 26 & 13.83 & 2 & 1.06 & 28 & 14.89 \\
\hline $8-10$ & 24 & 12.77 & 2 & 1.06 & 26 & 13.83 \\
\hline More than 10 & 4 & 2.13 & 0 & 0.00 & 4 & 2.13 \\
\hline \multicolumn{7}{|l|}{ Marital status } \\
\hline Single & 36 & 19.15 & 10 & 5.32 & 46 & 24.47 \\
\hline Married & 104 & 55.32 & 8 & 4.26 & 112 & 59.57 \\
\hline Separated & 8 & 4.26 & 0 & 0.00 & 8 & 4.26 \\
\hline Widowed & 14 & 7.45 & 4 & 2.13 & 18 & 9.57 \\
\hline Divorced & 4 & 2.13 & 0 & 0.00 & 4 & 2.13 \\
\hline \multicolumn{7}{|l|}{ Education } \\
\hline None & 44 & 23.40 & 2 & 1.06 & 46 & 24.47 \\
\hline Primary & 32 & 17.02 & 8 & 4.26 & 40 & 21.28 \\
\hline Secondary & 44 & 23.40 & 6 & 3.19 & 50 & 26.60 \\
\hline Tertiary & 12 & 6.38 & 4 & 2.13 & 16 & 8.51 \\
\hline Adult education & 8 & 4.26 & 0 & 0.00 & 8 & 4.26 \\
\hline Other non-formal & 26 & 13.83 & 2 & 1.06 & 28 & 14.89 \\
\hline \multicolumn{7}{|l|}{ Primary occupation } \\
\hline Fisherman & 122 & 64.89 & 16 & 8.51 & 138 & 73.40 \\
\hline Teaching & 0 & 0.00 & 2 & 1.06 & 2 & 1.06 \\
\hline Trader & 12 & 6.38 & 2 & 1.06 & 14 & 7.45 \\
\hline Okada rider & 4 & 2.13 & 0 & 0.00 & 4 & 2.13 \\
\hline Artisan & 12 & 6.38 & 0 & 0.00 & 12 & 6.38 \\
\hline Student & 4 & 2.13 & 0 & 0.00 & 4 & 2.13 \\
\hline Clerk & 2 & 1.06 & 0 & 0.00 & 2 & 1.06 \\
\hline Farmer & 6 & 3.19 & 0 & 0.00 & 6 & 3.19 \\
\hline Civil servant & 2 & 1.06 & 2 & 1.06 & 4 & 2.13 \\
\hline Sand loader & 2 & 1.06 & 0 & 0.00 & 2 & 1.06 \\
\hline
\end{tabular}


Table 1b. Description of variables used for analysis.

\begin{tabular}{|c|c|c|}
\hline Variable & Mean & Std. deviation \\
\hline \multicolumn{3}{|l|}{ Problems associated with flooding } \\
\hline Flooding as environmental problem & 0.6809 & 0.4674 \\
\hline Flooding disrupt economic activities & 0.6596 & 0.4751 \\
\hline Flooding leads to property loss & 0.6489 & 0.4786 \\
\hline Flooding leads to water contamination & 0.3723 & 0.4847 \\
\hline Flooding lead to human and livestock death & 0.2766 & 0.4485 \\
\hline Spend more on health during flooding & 0.1489 & 0.3570 \\
\hline \multicolumn{3}{|l|}{ Socio-economic characteristics } \\
\hline Sex & 0.8617 & 0.3461 \\
\hline Age & 33.8298 & 11.4990 \\
\hline Marital status & 0.7021 & 0.7988 \\
\hline Household size & 5.4043 & 3.4403 \\
\hline Education of house head & 6.6596 & 5.2378 \\
\hline Monthly income & 32638.3000 & 63213.6900 \\
\hline Fishing experience & 9.6383 & 11.2291 \\
\hline Membership of association & 0.6383 & 0.4818 \\
\hline \multicolumn{3}{|l|}{ Disease incidence } \\
\hline Malaria incidence during flooding & 0.2340 & 0.4245 \\
\hline Typhoid incidence during flooding & 0.2553 & 0.4372 \\
\hline Cholera incidence during flooding & 0.2340 & 0.4245 \\
\hline Diarrhea incidence during flooding & 0.2766 & 0.4485 \\
\hline Dysentery incidence during flooding & 0.1702 & 0.3768 \\
\hline Influenza incidence during flooding & 0.3191 & 0.4674 \\
\hline Tuberculosis incidence during flooding & 0.1383 & 0.3461 \\
\hline \multicolumn{3}{|l|}{ Other impacts and coping methods } \\
\hline More labour required during flooding & 0.7553 & 0.4310 \\
\hline Received warning signals & 0.1702 & 0.3768 \\
\hline Have other occupation & 0.3085 & 0.4631 \\
\hline Received help during flooding & 0.9149 & 0.2798 \\
\hline Migration & 0.5160 & 0.5011 \\
\hline Fish composition changed during flooding & 0.1277 & 0.3346 \\
\hline
\end{tabular}

are based on whether flooding is constituting a major environmental problem, disrupting economic activities, leading to lose of properties, leading to death, resulting into water contamination and households' spend more on health immediately after flooding. Table $1 \mathrm{~b}$ shows the description of the variables that were used for the analysis.

\section{Flooding as environmental problem}

Table 2 shows the Probit results for analyzing the factors predisposing flooding to constitute a major environmental problem to the fishing folks. The pseudo adjusted coefficient of determination shows that the model explained $26.88 \%$ of the variations in the probability. The computed Chi Square value for the likelihood ratio is statistically significant $(p<0.01)$. This shows that the model fits the data very appropriately.

Out of the included variables, fishing experience, higher incidence of influenza during flooding, tuberculosis during flooding, more labour required during flooding and having other occupation show some statistical significance $(p<0.10)$ and have varied signs. The results show that flooding is less likely to be an environmental problem to those with higher fishing experience, with reported cases of influenza and those with other occupations. Precisely, flooding constitutes some environmental problems as homes are flooded and debris of refuses liter the whole compound and rooms. Those with higher fishing experience are expected to have devised a better way of coping so that they are not always affected by flooding. 
Table 2. Probit regression of factors explaining flooding as the major environmental problem.

\begin{tabular}{lccc}
\hline Variable & Coefficients & Standard error & z value \\
\hline Socio-economic characteristics & & & \\
Sex & 0.2948 & 0.4058 & 0.73 \\
Age & -0.0005 & 0.0161 & -0.03 \\
Marital status & 0.1384 & 0.1850 & 0.75 \\
Household size & -0.0242 & 0.0461 & -0.53 \\
Education of house head & -0.0135 & 0.0244 & -0.55 \\
Monthly income & 0.0000 & 0.0000 & -0.89 \\
Fishing experience & $-0.0230^{*}$ & 0.0121 & -1.89 \\
Membership of association & 0.3981 & 0.3159 & 1.26 \\
& & & \\
Disease Incidence & & & \\
Malaria incidence during flooding & -0.2940 & 0.3541 & -0.83 \\
Typhoid incidence during flooding & 0.3762 & 0.3312 & 1.14 \\
Cholera incidence during flooding & -0.3113 & 0.3547 & -0.88 \\
Diarrhea incidence during flooding & -0.0722 & 0.3609 & -0.2 \\
Dysentery incidence during flooding & 0.6615 & 0.4444 & 1.49 \\
Influenza incidence during flooding & $-0.9214^{* * *}$ & 0.3138 & -2.94 \\
Tuberculosis incidence during flooding & $0.8988^{*}$ & 0.5098 & 1.76 \\
& & & \\
Other impacts and coping methods & & & \\
More labour required during flooding & $1.3554^{* * *}$ & 0.3512 & 3.86 \\
Fish composition changed during flooding & 0.3072 & 0.4503 & 0.68 \\
Received warning signals & 0.4606 & 0.3700 & 1.24 \\
Have other occupation & $-0.6159^{* *}$ & 0.2831 & -2.18 \\
Received help during flooding & -0.9359 & 0.5905 & -1.58 \\
Migration & -0.3841 & 0.2658 & -1.45 \\
Constant term & 0.7939 & 0.8032 & 0.99 \\
\hline
\end{tabular}

$\mathrm{LR} \mathrm{Chi}^{2}(21)=63.30$; Prob $>\mathrm{Chi}^{2}=0.0000$; Pseudo $\mathrm{R}^{2}=0.2688 ;{ }^{* *}$ Significant at $1 \%$; ${ }^{* *}$ Significant at $5 \%$, *Significant at $10 \%$.

Orlove et al. (2004) reported that some workers did switch to other occupations in the event of flooding (or reallocated their effort to secondary employment), but the opportunities in the labor market were extremely limited, due to the general economic downturn of the affected communities. However, those people with reported cases of tuberculosis after flooding and who would require more labour more their fishing activities during flooding have higher probability of seeing flooding as a major environmental problem. During flooding, Orlove et al. (2004) reported that transportation networks are often disrupted thus constituting serious environmental problem.

\section{Flooding disrupts economic activities}

Table 3 contains the result for those whose economic activities are disrupted by flooding. The Chi square of the likelihood ratio is also statistically significant $(p<0.01)$, showing that the model fits the data very well. Out of the variables that were included, age, household size, fishing experience, typhoid fever, cholera, dysentery, influenza, fish composition change, received warning, received assistance during flooding and migration are statistically significant $(p<0.10)$.

The results further show that those with more fishing experience have significantly lower probability of having their economic activities disrupted by flooding. However, those with large household size have significantly higher probability of having their economic activities affected by flooding. This may result from higher pressure to meet their needs. The health variables reveal that those that reported more cases of typhoid fever, cholera, and dysentery have higher probability of having their economic activities disrupted by flooding. Douglas et al. (2008) reported that in Sierra Leone, cholera and dysentery were largely associated with flooding with serious economic consequences. Those who received warning, and indicated that fish composition changes during flooding have higher probability of having their economic activities disrupted by flooding. The result for 
Table 3. Probit regression of factors explaining experience of activity disruption by flooding.

\begin{tabular}{|c|c|c|c|}
\hline Variable & Coefficients & Standard error & $z$ value \\
\hline \multicolumn{4}{|l|}{ Socio-economic characteristics } \\
\hline Sex & 0.2804 & 0.4074 & 0.69 \\
\hline Age & $-0.0418^{* *}$ & 0.0171 & -2.45 \\
\hline Marital status & 0.0397 & 0.1814 & 0.22 \\
\hline Household size & $0.1583^{\star \star *}$ & 0.0547 & 2.90 \\
\hline Education of house head & 0.0385 & 0.0258 & 1.49 \\
\hline Monthly income & 0.0000 & 0.0000 & 0.86 \\
\hline Fishing experience & $-0.0296^{* *}$ & 0.0120 & -2.46 \\
\hline Membership of association & 0.3218 & 0.3200 & 1.01 \\
\hline \multicolumn{4}{|l|}{ Disease Incidence } \\
\hline Malaria incidence during flooding & 0.2568 & 0.3640 & 0.71 \\
\hline Typhoid incidence during flooding & $0.7011^{*}$ & 0.3614 & 1.94 \\
\hline Cholera incidence during flooding & $0.7894^{*}$ & 0.4178 & 1.89 \\
\hline Diarrhea incidence during flooding & -0.4962 & 0.3650 & -1.36 \\
\hline Dysentery incidence during flooding & $0.8062^{*}$ & 0.4622 & 1.74 \\
\hline Influenza incidence during flooding & $-1.4635^{\star \star \star}$ & 0.3543 & -4.13 \\
\hline Tuberculosis incidence during flooding & 0.1673 & 0.4237 & 0.39 \\
\hline \multicolumn{4}{|l|}{ Other impacts and coping methods } \\
\hline More labour required during flooding & 0.5841 & 0.3597 & 1.62 \\
\hline Fish composition changed during flooding & $1.0106^{* *}$ & 0.4450 & 2.27 \\
\hline Received warning signals & $0.7401^{*}$ & 0.3886 & 1.90 \\
\hline Have other occupation & -0.4234 & 0.2918 & -1.45 \\
\hline Received help during flooding & $-1.4892^{\star *}$ & 0.6335 & -2.35 \\
\hline Migration & $-0.5305^{\star *}$ & 0.2630 & -2.02 \\
\hline Constant term & $1.7801^{* *}$ & 0.8322 & 2.14 \\
\hline
\end{tabular}

LR $\operatorname{chi}^{2}(21)=68.02$; Prob $>\operatorname{chi}^{2}=0.0000$; Pseudo $\mathrm{R}^{2}=0.2821 ;{ }^{* *}$ Significant at $1 \% ;{ }^{* *}$ Significant at $5 \%$; *Significant at $10 \%$.

warning is not what is expected. However, Orlove et al (2004) found that it is not in all cases that fishing folks take to warnings. However, those who received assistance during flooding have significantly lower probability of having their economic activities disrupted by flooding. Also, those that are able to migrate during flooding have significantly lower probability of having their economic activities disrupted by flooding. Douglas et al. (2008) identified migration as a viable form of adaptation being used by some flood affected households in Accra.

\section{Experience of property losses}

Table 4 shows the results of the analysis for those who indicated that they lose their properties during flooding. The Pseudo Adjusted R square implies that $29.64 \%$ of the variations in the values of the probabilities have been explained by the included variables. The likelihood ratio of the Chi Square is statistically significant $(p<0.01)$ and implies that the model produced a good fit for the data.
Out of the variables that were included, monthly income, diarrhea, more labour required, received warning signals, have other occupation and migration are statistically significant $(p<0.10)$.

Also, as monthly income increases, the probability of losing properties due to flooding significantly decreases. Those that required more labour and received initial warnings have significantly higher probability of losing their properties during flooding. Possession of other occupation significantly reduced the probability of losing properties due to flooding. Those that are able to migrate during flooding have significantly lower probability of losing their properties during flooding.

\section{Flooding leading to loss of life of human beings and livestock}

Table 5 estimated the equation for the likelihood of flooding resulting into death of human and animals. It should be noted that occasionally, flooding resulted into 
Table 4. Probit regression of factors explaining experience of property losses through flooding.

\begin{tabular}{|c|c|c|c|}
\hline Variable & Coefficients & Standard error & $z$ value \\
\hline \multicolumn{4}{|l|}{ Socio-economic characteristics } \\
\hline Sex & 0.1805 & 0.4012 & 0.45 \\
\hline Age & -0.0055 & 0.0163 & -0.34 \\
\hline Marital status & 0.3383 & 0.2242 & 1.51 \\
\hline Household size & 0.0719 & 0.0495 & 1.45 \\
\hline Education of house head & -0.0295 & 0.0243 & -1.22 \\
\hline Monthly income & $0.0000^{\star *}$ & 0.0000 & -2.06 \\
\hline Fishing experience & -0.0181 & 0.0122 & -1.48 \\
\hline Membership of association & -0.1862 & 0.3116 & -0.6 \\
\hline \multicolumn{4}{|l|}{ Disease incidence } \\
\hline Malaria incidence during flooding & 0.0483 & 0.3410 & 0.14 \\
\hline Typhoid incidence during flooding & 0.3453 & 0.3136 & 1.1 \\
\hline Cholera incidence during flooding & -0.0461 & 0.3811 & -0.12 \\
\hline Diarrhoe incidence during flooding & $-0.7107^{\star *}$ & 0.3358 & -2.12 \\
\hline Dysentery incidence during flooding & 0.5248 & 0.4258 & 1.23 \\
\hline Influenza incidence during flooding & 0.4362 & 0.3450 & 1.26 \\
\hline Tuberculosis incidence during flooding & 0.5398 & 0.4947 & 1.09 \\
\hline \multicolumn{4}{|l|}{ Other impacts and coping methods } \\
\hline More labour required during flooding & $0.8018^{\star *}$ & 0.3502 & 2.29 \\
\hline Fish composition changed during flooding & 0.7865 & 0.4943 & 1.59 \\
\hline Received warning signals & $1.2896^{* * *}$ & 0.4564 & 2.83 \\
\hline Have other occupation & $-0.4675^{\star}$ & 0.2814 & -1.66 \\
\hline Received help during flooding & -0.2510 & 0.4640 & -0.54 \\
\hline Migration & $-0.4687^{*}$ & 0.2608 & -1.8 \\
\hline Constant term & 0.1179 & 0.7381 & 0.16 \\
\hline
\end{tabular}

$\operatorname{LR} \operatorname{chi}^{2}(21)=72.23$, Prob $>$ chi $^{2}=0.0000$, Pseudo $R^{2}=0.2964 ;{ }^{* * *}$ Significant at $1 \% ;{ }^{* *}$ Significant at $5 \%$; *Significant at $10 \%$.

Table 5. Probit regression of factors explaining experience of death through flooding.

\begin{tabular}{lccc}
\hline Variable & Coefficients & Standard error & z value \\
\hline Socio-economic characteristics & & & \\
Sex & 0.1955 & 0.5551 & 0.35 \\
Age & 0.0001 & 0.0182 & 0 \\
Marital status & -0.0540 & 0.1887 & -0.29 \\
Household size & 0.0155 & 0.0529 & 0.29 \\
Education of house head & 0.0015 & 0.0279 & 0.05 \\
Monthly income & $0.0000^{\star *}$ & 0.0000 & 2.11 \\
Fishing experience & $-0.0262^{\star *}$ & 0.0131 & -2.00 \\
Membership of association & 0.0061 & 0.3443 & 0.02 \\
& & & \\
Disease incidence & & & \\
Malaria incidence during flooding & -0.0132 & 0.3597 & -0.04 \\
Typhoid incidence during flooding & 0.5640 & 0.3513 & 1.61 \\
Cholera incidence during flooding & -0.2110 & 0.3898 & -0.54 \\
Diarrhoe incidence during flooding & -0.1117 & 0.3572 & -0.31 \\
Dysentery incidence during flooding & $-2.4278^{\star * *}$ & 0.6407 & -3.79 \\
Influenza incidence during flooding & $1.4761^{\star * *}$ & 0.3886 & 3.8 \\
\hline
\end{tabular}


Table 5. Contd.

\begin{tabular}{lccc}
\hline Tuberculosis incidence during flooding & $2.4110^{\star * *}$ & 0.6080 & 3.97 \\
Other impacts and coping methods & & & \\
More labour required during flooding & 0.6130 & 0.4351 & 1.41 \\
Fish composition changed during flooding & 0.2337 & 0.4421 & 0.53 \\
Received warning signals & -0.8129 & 0.3874 & -2.1 \\
Have other occupation & $0.6360^{\star *}$ & 0.2844 & 2.24 \\
Received help during flooding & -0.0041 & 0.5792 & -0.01 \\
Migration & $1.0947^{\star * *}$ & 0.3173 & 3.45 \\
Constant term & $-2.2677^{\star *}$ & 0.9288 & -2.44 \\
\hline
\end{tabular}

LR chi $^{2}(21)=95.22$; Prob $>$ chi $^{2}=0.0000$; Pseudo $R^{2}=0.3836 ;{ }^{* *}$ Significant at $1 \%$; ${ }^{*}$ Significant at $5 \%$; ${ }^{*}$ Significant at $10 \%$.

death of human beings in the study area. However, the majority of those who indicated to be affected in this category of analysis only lost their livestock. The pseudo $R$ square indicated that $38.36 \%$ of the variations in the values of the probabilities have been explained by the included variables.

As the monthly income increases, the probability of suffering loses of livestock due to flooding increases. Those who reported higher incidence of influenza and tuberculosis also have significantly higher probability of experiencing death of livestock/human due to flooding. Those that received warning signals have significantly lower probability of suffering loss of livestock during flooding. Also, those that have other occupations have higher probability of suffering losses of livestock due to flooding. Those that indicated to be migrating due to flooding have significantly higher probability of suffering death of humans and livestock due to flooding.

\section{Water contamination through flooding}

Table 6 shows the results of Probit regression explaining the factors that are associated with those that indicated to be suffering water contamination due to flooding. The Pseudo Adjusted R Square indicates that $53.57 \%$ of the variations in the probability of suffering water contamination due to flooding. The chi square of the likelihood ratio is also statistically significant $(p<0.01)$. Those variables that are statistically significant $(p<0.10)$ are sex, education, fishing experience, membership of association, malaria, typhoid, cholera, dysentery, and fish composition changed due to flooding.

Being a male respondent significantly reduces the probability of having water contaminated due to flooding. Also, as the years of education and fishing experience increase, the probability of having water contaminated through flooding increases. Membership of associations significantly reduces the probability of having water contaminated by flooding. Those that indicated to suffer more incidences of malaria, cholera, and dysentery have significantly probability of having their water contaminated by flooding. However, contrary to expectation, those that indicated more incidences of typhoid fever and diarrhea during flooding have significantly lower probability of having their water contaminated. Also, those that indicated that the composition of fish changes after flooding have significantly higher probability of having their waters contaminated.

\section{Health expenditures increases during flooding}

Table 7 shows the Probit regression results of the factors explaining spending more on health during flooding. The pseudo coefficient of determination shows that $61.22 \%$ of the variations in the values of probability are explained by the included variables. The Likelihood ratio chi square is also statistically significant $(p<0.01)$. Out of the variables that were included, marital status, household size, education, fishing experience, malaria, cholera, diarrhea, influenza, tuberculosis and migration are statistically significant $(p<0.10)$.

The results show that those that are married have significantly higher probability of spending more on health during flooding. However, contrary to expectation, household size variable has negative sign, implying that those that have higher family size have significantly lower probability of spending more on health during flooding. Also, as households' education increases, the probability of spending more on health during flooding increases. As fishing experience increases, the probability of spending more on health during flooding increases. The included health variables shows that those that indicated higher incidence of malaria and diarrhea have significantly lower probability of spending more on health during flooding. However, those that indicated higher incidence of influenza and tuberculosis during flooding have significantly higher probability of spending more on health during flooding. Those that indicated to be migrating due to flooding have significantly higher probability of spending more on health during flooding. 
Table 6. Probit regression results of factors explaining suffering water contamination due to flooding.

\begin{tabular}{|c|c|c|c|}
\hline Variable & Coefficients & Standard error & $z$ value \\
\hline \multicolumn{4}{|l|}{ Socio-economic characteristics } \\
\hline Sex & $-2.2774^{\star *}$ & 0.8911 & -2.56 \\
\hline Age & 0.0179 & 0.0270 & 0.66 \\
\hline Marital status & 0.2645 & 0.1733 & 1.53 \\
\hline Household size & -0.1062 & 0.0723 & -1.47 \\
\hline Education of house head & $0.0613^{*}$ & 0.0315 & 1.95 \\
\hline Monthly income & 0.0000 & 0.0000 & 0.15 \\
\hline Fishing experience & $0.0530^{* * *}$ & 0.0187 & 2.84 \\
\hline Membership of association & $-0.7084^{*}$ & 0.4083 & -1.74 \\
\hline \multicolumn{4}{|l|}{ Disease incidence } \\
\hline Malaria incidence during flooding & $1.8704^{\star \star *}$ & 0.4969 & 3.76 \\
\hline Typhoid incidence during flooding & $-2.3220^{\star * *}$ & 0.6945 & -3.34 \\
\hline Cholera incidence during flooding & $2.1653^{\star * *}$ & 0.7618 & 2.84 \\
\hline Diarrhoe incidence during flooding & $-2.2979^{* * *}$ & 0.8659 & -2.65 \\
\hline Dysentery incidence during flooding & $2.6946^{\star \star *}$ & 0.6472 & 4.16 \\
\hline Influenza incidence during flooding & -0.2384 & 0.4213 & -0.57 \\
\hline Tuberculosis incidence during flooding & -0.5632 & 0.6192 & -0.91 \\
\hline \multicolumn{4}{|l|}{ Other impacts and coping options } \\
\hline More labour required during flooding & $1.8708^{\star *}$ & 0.7781 & 2.4 \\
\hline Fish composition changed during flooding & $1.9174^{\star \star}$ & 0.5232 & 3.66 \\
\hline Received warning signals & -0.2859 & 0.4483 & -0.64 \\
\hline Have other occupation & -0.5244 & 0.4127 & -1.27 \\
\hline Received help during flooding & 0.0978 & 0.6659 & 0.15 \\
\hline Migration & 0.2299 & 0.3624 & 0.63 \\
\hline Constant term & -1.7186 & 1.0788 & -1.59 \\
\hline
\end{tabular}

$\operatorname{LR} \operatorname{chi}^{2}(21)=118.78$; Prob $>\operatorname{chi}^{2}=0.0000$; Pseudo $\mathrm{R}^{2}=0.5357 ;{ }^{* *}$ Significant at $1 \%$; ${ }^{* *}$ Significant at $5 \%$; ${ }^{*}$ Significant at $10 \%$.

Table 7. Probit regression results of factors explaining spending more on health due to flooding.

\begin{tabular}{lccc}
\hline Variable & Coefficients & Standard error & z value \\
\hline Socio-economic characteristics & & & \\
Sex & -6.7524 & 33.3082 & -0.2 \\
Age & 0.0119 & 0.0437 & 0.27 \\
Marital status & $0.9249^{* *}$ & 0.4115 & 2.25 \\
Household size & $-0.2652^{*}$ & 0.1484 & -1.79 \\
Education of house head & $0.2917^{* * *}$ & 0.1108 & 2.63 \\
Monthly income & 0.0000 & 0.0000 & 0.09 \\
Fishing experience & $0.0819^{* *}$ & 0.0345 & 2.37 \\
Membership of association & -0.6755 & 0.8064 & -0.84 \\
& & & \\
Disease incidence & & & \\
Malaria incidence during flooding & $-1.1217^{*}$ & 0.6039 & -1.86 \\
Typhoid incidence during flooding & 0.4943 & 0.6735 & 0.73 \\
Cholera incidence during flooding & $3.4892^{* * *}$ & 1.3218 & 2.64 \\
Diarrhoe incidence during flooding & $-1.5441^{*}$ & 0.9242 & -1.67 \\
Dysentery incidence during flooding & -0.5682 & 0.7670 & -0.74 \\
Influenza incidence during flooding & $2.1866^{* *}$ & 0.9210 & 2.37 \\
\hline
\end{tabular}


Table 7. Contd.

\begin{tabular}{lccc}
\hline Tuberculosis incidence during flooding & $3.2557^{\star * *}$ & 0.9758 & 3.34 \\
Other impacts and coping methods & & & \\
More labour required during flooding & 4.0276 & 33.2485 & 0.12 \\
Fish composition changed during flooding & 1.0855 & 0.8386 & 1.29 \\
Received warning signals & -2.0572 & 1.0311 & -2 \\
Have other occupation & -0.4889 & 0.6835 & -0.72 \\
Received help during flooding & 1.6289 & 1.1271 & 1.45 \\
Migration & $2.0575^{\star *}$ & 0.8811 & 2.34 \\
Constant term & $-6.3282^{* *}$ & 2.5501 & -2.48 \\
\hline
\end{tabular}

LR $\operatorname{chi}^{2}(21)=96.88$; Prob $>\mathrm{chi}^{2}=0.0000$; Pseudo $\mathrm{R}^{2}=0.6122 ;{ }^{* *}$ Significant at $1 \% ;{ }^{*}$ Significant at $5 \%$; ${ }^{*}$ Significant at $10 \%$.

Table 8. Tobit regression results of factors influence amounts willing to pay for insurance against flooding.

\begin{tabular}{lccc}
\hline Variable & Coefficients & Standard error & z value \\
\hline Socio-economic characteristics & & & \\
Sex & $-1281.3100^{* * *}$ & 442.1992 & -2.9 \\
Age & -3.9920 & 16.3067 & -0.24 \\
Marital status & 124.3315 & 178.7979 & 0.7 \\
Household size & -32.3062 & 46.9974 & -0.69 \\
Education of house head & $41.5010^{*}$ & 23.8260 & 1.74 \\
Monthly income & 0.0040 & 0.0017 & 2.3 \\
Fishing experience & $21.3371^{*}$ & 11.2567 & 1.9 \\
Membership of association & -216.2850 & 308.3372 & -0.7 \\
Malaria incidence during flooding & $489.5611^{*}$ & 298.4399 & 1.64 \\
& & & \\
Disease incidence & & & \\
Typhoid incidence during flooding & 417.9736 & 299.2814 & 1.4 \\
Cholera incidence during flooding & 403.3123 & 338.4940 & 1.19 \\
Diarrhoe incidence during flooding & -94.8162 & 328.6289 & -0.29 \\
Dysentery incidence during flooding & -5.4967 & 376.6810 & -0.01 \\
Influenza incidence during flooding & 101.5781 & 310.8857 & 0.33 \\
Tuberculosis incidence during flooding & -214.2830 & 375.4206 & -0.57 \\
Other impacts and coping methods & & & \\
More labour required during flooding & $1047.5220^{* *}$ & 416.7032 & 2.51 \\
Fish composition changed during flooding & 206.1422 & 380.6176 & 0.54 \\
Received warning signals & $-678.8190^{*}$ & 382.9870 & -1.77 \\
Have other occupation & 269.5328 & 250.9725 & 1.07 \\
Received help during flooding & $-1212.2300^{* * *}$ & 387.5425 & -3.13 \\
Migration & -375.4150 & 262.0193 & -1.43 \\
Constant term & 444.2584 & 672.3573 & 0.66 \\
Sigma & 1170.3100 & 113.7827 & 10.2854828 \\
\hline
\end{tabular}

${ }^{\star \star *}$ Significant at $1 \% ;{ }^{* \star}$ Significant at $5 \% ;{ }^{*}$ Significant at $10 \%$.

\section{Tobit regression results of amounts willing to pay for insurance against flooding}

Table 8 shows the results of the factors influencing the amounts that fishing folks are willing to pay for insurance against flooding. The pseudo coefficient of determination shows that $4.11 \%$ of the variations in the amounts that are willing to pay have been explained by the included variables. The likelihood ratio chi square is statistically significant $(p<0.01)$. The sigma parameter is also 
statistically significant. This shows that the model produced a good fit for the data.

The results show that the parameters of sex, education, income, fishing experience, malaria, more labour required during flooding, received warning signals and received help during flooding are statistically significant $(p<0.01)$. The amounts that the males fishing folks are willing to pay are significantly lower than that of the female. Also, as education and monthly income increase, the amounts that are willing to be paid significantly increase. As the fishing experience increases, the amounts being willing to pay significantly increases. Those that indicated that more labour are always required for fishing during flooding are willing to pay significantly higher amount for insurance. However, those that indicated to have received warning signals and assistance during flooding are willing to pay significantly lower amounts.

\section{Conclusions}

This study was borne out of a desire to study climate change impacts in Lagos with a focus on naturally caused flooding and how the artisannal fishermen are affected because of the pertinent role they play in ensuring food security of the nation. It is obvious that there are many varied impacts on the economy and the need for adaptation as well as mitigation studies and interventions cannot be overemphasized. Given the results of our analyses, the following policy issues clearly emerge from this study:

1. Flooding is an environmental problem that affects majority of the coastal fishing folks, and efforts to mitigate its impact should be earnestly devised. This becomes important due to losses of lives and properties. There is need for government's interventions in ensuring alternative skill development for those along the coast. This is important because possession of alternative occupation reduces vulnerability risks in most of our results.

2. We found that migration and offering of assistances are important factors for reducing vulnerability to some adverse consequences of flooding. There is the need for stakeholders' interventions in providing permanent refugee camps for those that are likely to be affected by flooding. This shows that resettlement may be a workable option. Although this may be abused in a kind of mega city like Lagos, development of appropriate modality for resettlement will assist in averting future problems.

3. Government's interventions in providing affordable health services to those affected by flood are also promising. This is particularly welcomed for treatment of disease outbreaks like malaria, cholera and dysentery that are highly associated with flooding.

4. Proper development of early warning signal is also essential for reducing vulnerability. Such information may be passed gathered via monitoring by appropriate agencies in Lagos and passed to the people through such media as radio and community leaders.

\section{REFERENCES}

Awosika LF, French GT, Nicholls RJ, Ibe CE (1992). The Impact of Sea level Rise on the Coastline of Nigeria. In: Proceedings of IPCC Symposium on the Rising Challenges of the Sea. Magaritta, Venezuela. 14-19 March, 1992.

Ayo-Lawal G (2007). Showers of Agony, Ruin and Death" Nigerian Tribune Wed.28 ${ }^{\text {th }}$ Nov. 2007. http://www.tribune.com.ng

Blaikie P (1994). At Risk: Natural Hazards, People's Vulnerability and Disasters, Routledge, LondonBotkin

Douglas I, Alam K, Maghenda M, Mcdonnell Y, Mclean L, Campbell J. (2008). Unjust Waters: Climate Change, Flooding and the Urban Poor in Africa. Environ. Urbanization 20(1):187-205.

Haakonsen MJ (1992). West African Artisanal Fisheries, In: Fishing For Development: Small-Scale Fisheries in Africa, Tredten I, Hersoug B (eds.) The Scandinavian Institute of African Studies, Uppsala, Motala, Grafisca AB Motala, (1992).

IPCC (2001). Climate Change 2001: Impacts, Adaptation and Vulnerability, contribution of Working Group II to the Third Assessment Report of the IPCC, Cambridge University Press, New York.

Jepma C, Munasinghe M (1998). Climate Change Policy: Facts, Issues and Analyses, Cambridge University Press, Cambridge

Jinadu OO (2003). Small-Scale Fisheries In Lagos State, Nigeria: Economic Sustainable Yield Determination." Federal College of Fisheries and Marine Technology Wilmot Point, Victoria Island, Lagos, Nigeria (2003).

Komen G, Smith N (1999). Wave and Sea Level Monitoring and Prediction in the Services Module of the Global Ocean Observing System (GOOS). J. Mar. Syst19:35-250.

Leary N, Beresford S (2007). Vulnerability of people, places, and systems to environmental change. In: Knight, G. and Jaeger, J. (eds) Integrated regional assessment. Cambridge University Press, Cambridge, UK.

Lowe JA, Gregory JM, Flather RA. (2001): Changes in the occurrence of storm surges around the United Kingdom under a future climate scenario using a dynamic storm surge model driven by Hadley Center climate models. Climate Dynamics. 18:179- 188.

Maddison D (2006). The Perception of and Adaptation to Climate Change in Africa. CEEPA. Discussion Paper No. 10. Centre for Environmental Economics and Policy in Africa. Pretoria, South Africa: University of Pretoria.

Marfai MA, King L (2007). Coastal Flood Management in Semarang, Indonesia. Environ Geol

Murty TS (1984). Storm Surges - Meteorological Ocean Tides. Canadian Bulletin of Fisheries and Aquatic Science. P. 212.

Okali D, Eleri EO (2004). Climate Change and Nigeria: A Guide for Policy Makers. The Publication of the Nigerian Environmental Study Action Team (NEST)

Olaniyan E, Afiesimama EA (2002). On Marine Winds Waves and Swells Over the West African Coast for Effective Coastal Management: A Case Study of the Victoria Island Beach. Proceedings of Ocean 2002 MTS/IEEE Conference Oct 29-31 Biloxi, Mississippi. pp. 561-568.

Orlove BS, Broad K, Petty AM (2004). Factors That Influence the Use of Climate Forecasts: Evidence from the 1997/98 El Niño Event in Peru.

Osman-Elasha B, Spanger-Siegfried E, Goutbi N, Zakieldin S, Hanafi A (2007). Sustainable Livelihood Measures: Lessons for Climate Change Adaptation in Arid Regions of Africa. Annals of Arid Zone 44(3\&4):403-419.

Sivakumar MVK (2005). Impacts of Natural Disasters in Agriculture, Rangeland and Forestry: An Overview. In: Sivakumar MVK, Motha RP, Das HP (eds) Natural Disasters and Extreme Events in Agriculture, Impacts and Mitigation. World Meteorological Organization, Geneva

The Office of the High Commission for Human Right (1966). 
International Covenant on Economic, Social and Cultural Rights Adopted and opened for signature, ratification and accession by General Assembly resolution 2200A (XXI) of 16 December 1966, Internet file downloaded from http://www.unhchr.ch/html/menu3/b/a_cescr.htm on 9th August 2008.

Udofa IM, Fajemirokun FA (1978). On A Height Datum for Nigeria. In Proceedings: International Symposium on Geodetic Measurements and Computations. Ahmadu Bello University, Zaria, Nigeria.

United Nations (2007). The Millennium Development Goals Report 2007

United Nations Development Programme. Poverty Eradication, MDGs and Climate Change. Internet file downloaded from http://www.undp.org/climatechange/adap01.htm on 7th August 2008.

UNESCO/CSI (2000). Special Project: Study of Main Drainage Channels of Victoria and Ikoyi Islands in Lagos Nigeria and their Response to Tidal and Sea Level Changes (2000). http://www.unesco.org/csi
UNFCCC (2002). Report of the Conference of Parties on its Seventh Session held at Marrakesh from 29th October to 10th November 2001: Part II - Action Taken by the Conference of Parties.

Uyigue E (2007) Climate Change in the Niger Delta. Internet file downloaded

from http://www.ciel.org/Publications/Climate/CaseStudy_Nigeria_Dec07.p df On $5^{\text {th }}$ August 2008. 